ISSN = 1980-993X-doi:10.4136/1980-993X
www.ambi-agua.net
E-mail: ambi-agua@agro.unitau.br
Tel.: (12) 3625-4212

\title{
The effect of indigenous probiotics on egg hatchability and larval viability of Clarias gariepinus
}

(http://dx.doi.org/10.4136/ambi-agua.712)

\author{
Caroline N. Ariole ${ }^{1}$; Gideon C. Okpokwasili \\ Department of Microbiology, University of Port Harcourt, \\ P.M.B. 5323, Port Harcourt, Rivers State, Nigeria \\ e-mail: cnariole@yahoo.com; ${ }^{2}$ e-mail: gidsilman@yahoo.com
}

\begin{abstract}
The effect of a mixture of four indigenous bacterial genera composed of Bacillus, Pseudomonas, Acinetobacter and Flavobacterium on egg hatchability and larval viability of Clarias gariepinus was investigated. The fertilized eggs were distributed into glass Petri dishes (100 mm diameter) containing $50 \mathrm{ml}$ of water at graded level of mixed indigenous probiotics ranging from $0-10^{8}$ cells $/ \mathrm{ml}$. The incubation time increased from 17 hours at 0 $\mathrm{cfu} / \mathrm{ml}$ to 22 hours at $10^{8} \mathrm{cfu} / \mathrm{ml}$. The mean hatching rate increased from $8.70 \%$ at $0 \mathrm{cfu} / \mathrm{ml}$ to $53.85 \%$ at $10^{8} \mathrm{cfu} / \mathrm{ml}$. The highest larval survival of $71.43 \%$ recorded at $10^{8} \mathrm{cfu} / \mathrm{ml}$ where the highest hatching rate was observed, was significantly higher than the larval survival rate observed at the other concentrations. All yolk sac larvae at 0 and $10^{1} \mathrm{cfu} / \mathrm{ml}$ died before the end of yolk sac period. These results imply that the incubation time, hatching rate and larval survival of Clarias gariepinus increased with increase in bacterial load of water up to $10^{8}$ cells $/ \mathrm{ml}$, the highest dose employed. Further investigations are needed to establish the optimal and threshold doses.
\end{abstract}

Keywords: Clarias eggs; incubation; rearing; indigenous probiotics; yolk sac larvae.

\section{O efeito dos probióticos naturais sobre a eclodibilidade de ovos e viabilidade das larvas de Clarias gariepinus}

\section{RESUMO}

O efeito de uma mistura de quatro géneros bacterianos naturais compostos de Bacillus, Pseudomonas, Acinetobacter e Flavobacterium sobre a eclodibilidade dos ovos e viabilidade das larvas de Clarias gariepinus foi investigado. Os ovos fertilizados foram distribuídos em placas de Petri de vidro (100 mm de diâmetro) contendo $50 \mathrm{ml}$ de água, adicionando-se probióticos naturais mistos que variaram de $0-10^{8}$ células $/ \mathrm{ml}$. O tempo de incubação aumentou de 17 horas a $0 \mathrm{ufc} / \mathrm{ml}$ para 22 horas a $10^{8} \mathrm{ufc} / \mathrm{ml}$. A taxa de eclosão média aumentou de $8,70 \%$ a $0 \mathrm{ufc} / \mathrm{ml}$ para $53,85 \%$ a $10^{8}$ ufc $/ \mathrm{ml}$. A maior taxa de sobrevivência das larvas foi de $71,43 \%$ observada em $10^{8} \mathrm{ufc} / \mathrm{ml}$, significativamente mais elevada do que a taxa de sobrevivência das larvas observada nas outras concentrações. Todas as larvas em fase embrionária na concentração de 0 e $10^{1} \mathrm{cfu} / \mathrm{ml}$ morreram antes do final do período embrionário da gema. Estes resultados implicam que o tempo de incubação, a taxa de eclosão e a sobrevivência das larvas de Clarias gariepinus apresentaram os melhores resultados com a concentração bacteriana na água de até $10^{8}$ 
ARIOLE, C. N.; OKPOKWASILI, G. C. The effect of indigenous probiotics on egg hatchability and larval viability of Clarias gariepinus. Ambi-Agua, Taubaté, v. 7, n. 1, p. 81-88, 2012. (http://dx.doi.org/10.4136/ambi-agua.712)

células/ml, ou seja, com a dose mais elevada utilizada. Investigações adicionais são necessárias para estabelecer as doses ótimas e os níveis limites.

Palavras-chave: Ovos de Clarias; incubação; criação; probióticos naturais; larvas de gemas embrionárias.

\section{INTRODUTION}

The African catfish Clarias gariepinus is distributed throughout Africa. It is of growing economic value in the African aquaculture industry (Goda et al., 2007; Osman et al., 2007; Aldelhamid, 2009). In Nigeria, Clarias gariepinus is very well accepted by fish farmers and consumers and are therefore very indispensable to the sustainability of aquaculture. One of the limiting factors in fish production is mortality due to microbial infections and hatcheries and nurseries are known to be point sources of infection (Delince et al., 1987). Disease reduces hatchery efficiency and production which in turn, increases costs and reduces profit. There is, therefore, an urgent need to control the microbiota in hatching incubators by alternative means, since the use of antibiotic has to be minimal. In fact, the use of antibiotics does not allow microbial control and may result in an unfavorable alteration of the microbiota (Hansen et al., 1992; Olafsen, 1998). The introduction of microbial control practices by means of probiotics may have a beneficial effect on the cultures (Olafsen, 1998).

The development of non - antibiotic and friendly agents is one of the key factors for health management in aquaculture. This is because the use of expensive chemotherapeutants for controlling diseases have been widely criticized for their negative impacts (Sahu et al., 2008). The development and spread of antimicrobial resistant human pathogens (motile Aeromonas spp., E. tarda, E. coli, V. vulrificus, V. para haemolyticus, $V$. cholerae etc.) were well- documented (WHO, 1999). Aquatic bacteria can also develop resistance genes as a consequence of exposure to antimicrobial agents (Smith et al., 1994; Kim et al., 2004; S Ørum, 2006). Also, the occurrence of antimicrobial residues in products of aquaculture threat human health (WHO, 2006).

Probiotics which can be administered by direct addition of the organisms to the tanks, or by incorporation of the organisms into live or formulated feed is yet to gain popularity in aquaculture of Nigeria. The research of probiotics in aquaculture in Nigeria is still in its early stage. At present data about the effect of probiotics on tropical freshwater fish hatchery system is still lacking. Therefore, the aim of this investigation was to study the effect of graded level of a mixture of indigenous bacteria previously isolated from fish hatchery environment (Molokwu and Okpokwasili, 2002) on egg hatchability and larval viability of Clarias gariepinus as a part of a long term investigation into screening new probiotic strains from local aquaculture rearing unit to suit the specific requirement in Nigeria.

\section{MATERIALS AND METHODS}

The eggs of Clarias gariepinus were obtained from the hatchery at the African Regional Aquaculture centre (ARAC) Aluu, Port Harcourt, Nigeria by artificial breeding of the brood fish as described by Delince et al. (1987). Final maturation followed by ovulation was induced in female spawners with hormone treatment. The riped eggs were procured by stripping and milt was procured by dissection of a male donor. Few drops of milt solution were added onto the eggs and the sexual products mixed by gentle shaking of the bowl. The eggs were taken to the laboratory within 10 minutes of collection and 
ARIOLE, C. N.; OKPOKWASILI, G. C. The effect of indigenous probiotics on egg hatchability and larval viability of Clarias gariepinus. Ambi-Agua, Taubaté, v. 7, n. 1, p. 81-88, 2012. (http://dx.doi.org/10.4136/ambi-agua.712)

fertilized by adding approximately the same volume of clean water. The water and egg mass were thoroughly mixed by gently shaking the bowl.

The fertilized eggs were distributed into glass Petri dishes (100 $\mathrm{mm}$ diameter) containing $50 \mathrm{ml}$ of water at different concentrations of mixed indigenous probiotics. Four bacterial genera (Bacillus, Pseudomonas, Acinetobacter and Flavobacterium) previously isolated from fish hatchery systems (Molokwu and Okpokwasili, 2002) were grown at $30^{\circ} \mathrm{C}$ in nutrient broth for 24 hours. The bacterial cells were then harvested by centrifugation at 5,000 rpm for 20 minutes at room temperature $\left(28^{\circ} \mathrm{C}\right)$. The cells were washed twice, resuspended in $10 \mathrm{~mL}$ of sterile normal saline $(0.85 \% \mathrm{NaCl})$ and added to the Petri dishes at a final concentration ranging from $10^{1}-10^{8} \mathrm{cfu} / \mathrm{ml}$. The dilution water (borehole water) with physico-chemical characteristics as shown in Table 1 was used as control. Each treatment had three replicates.

Table 1. Physico-chemical characteristics of borehole water used for dilution.

\begin{tabular}{l|r}
\hline \multicolumn{1}{c|}{ Parameters } & Values \\
\hline $\mathrm{pH}$ & 6.50 \\
Total alkalinity $\left(\mathrm{mg} / \mathrm{L} \mathrm{CaCO}_{3}\right)$ & 9.00 \\
Total Hardness $\left(\mathrm{mg} / \mathrm{L} \mathrm{CaCO}_{3}\right)$ & 10.00 \\
$\mathrm{SO}_{4}{ }^{2-}-\mathrm{S}(\mathrm{mg} / \mathrm{L})$ & 0.00 \\
$\mathrm{NH}_{3}-\mathrm{N}(\mathrm{mg} / \mathrm{L})$ & 0.02 \\
$\mathrm{PO}_{4}{ }^{3-}-\mathrm{P}(\mathrm{mg} / \mathrm{L})$ & 0.00 \\
Salinity $(\mathrm{ppt})$ & 0.00 \\
Phenolphthalein alkalinity $\left(\mathrm{mg} / \mathrm{L}\right.$ as $\left.\mathrm{CaCO}_{3}\right)$ & 0.00 \\
\hline
\end{tabular}

The initial number of fertilized eggs in each Petri dish was noted. Dead eggs and larvae were removed with forceps. The duration of incubation time (from fertilization to first hatch) was recorded for each treatment. The hatched eggs were counted and the percentage determined for each treatment.

During larval rearing, incubation remnants, dead larvae and waste matter were siphoned off every day to avoid any form of stress and $50 \%$ of the water in each Petri dish was replaced. Three development periods were defined - the egg period, the hatching period and the yolk-sac period. The egg period began from the time of placement and ended when the eggs began to hatch. The hatching period began when first eggs hatched and ended when all eggs had hatched. The yolk-sac period extended from the end of the hatching period until the yolk-sac of the fry were absorbed (yolk-sac absorption was determined visually). The percentage survival of eggs and larvae at the end of each developmental period was determined. Data on hatchability and larval survival were analyzed using one-way analysis of variance (ANOVA) and Duncan multiple Range Test (DMRT). Significance was established at the 0.05 level.

\section{RESULTS AND DISCUSSION}

The effects of graded levels of a mixture of indigenous probiotics on incubation period presented in Figure 1 revealed that the incubation time increased from 17 hours at 0 $\mathrm{cfu} / \mathrm{ml}$ to 22 hours at $10^{8} \mathrm{cfu} / \mathrm{ml}$. The mean hatching rate increased from $8.70 \%$ at $0 \mathrm{cfu} / \mathrm{ml}$ to $53.85 \%$ at $10^{8} \mathrm{cfu} / \mathrm{ml}$, the highest concentration employed (Figure 2). 
ARIOLE, C. N.; OKPOKWASILI, G. C. The effect of indigenous probiotics on egg hatchability and larval viability of Clarias gariepinus. Ambi-Agua, Taubaté, v. 7, n. 1, p. 81-88, 2012. (http://dx.doi.org/10.4136/ambi-agua.712)

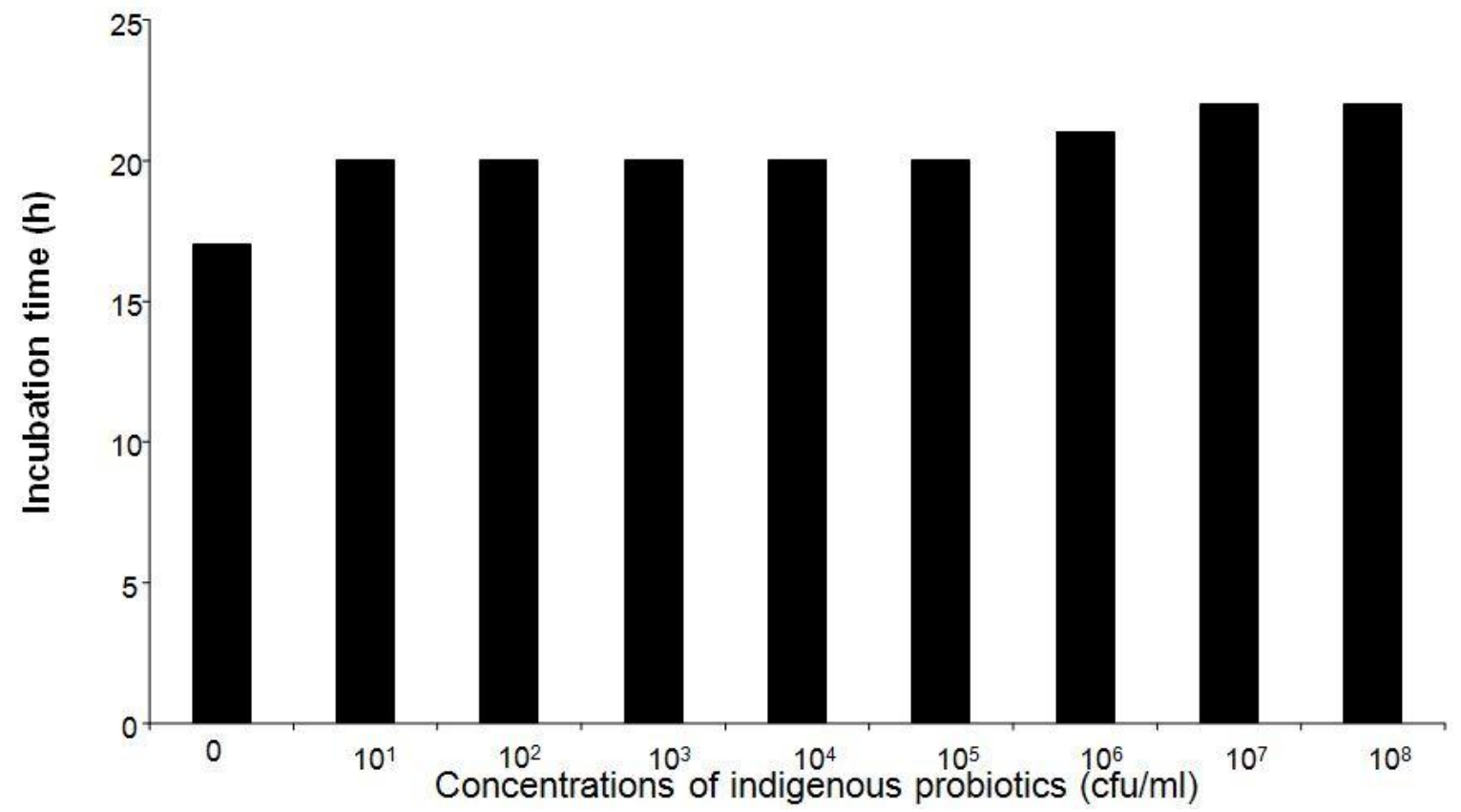

Figure 1. Incubation time to hatching of Clarias gariepinus egg exposed to different concentrations of indigenous probiotics.

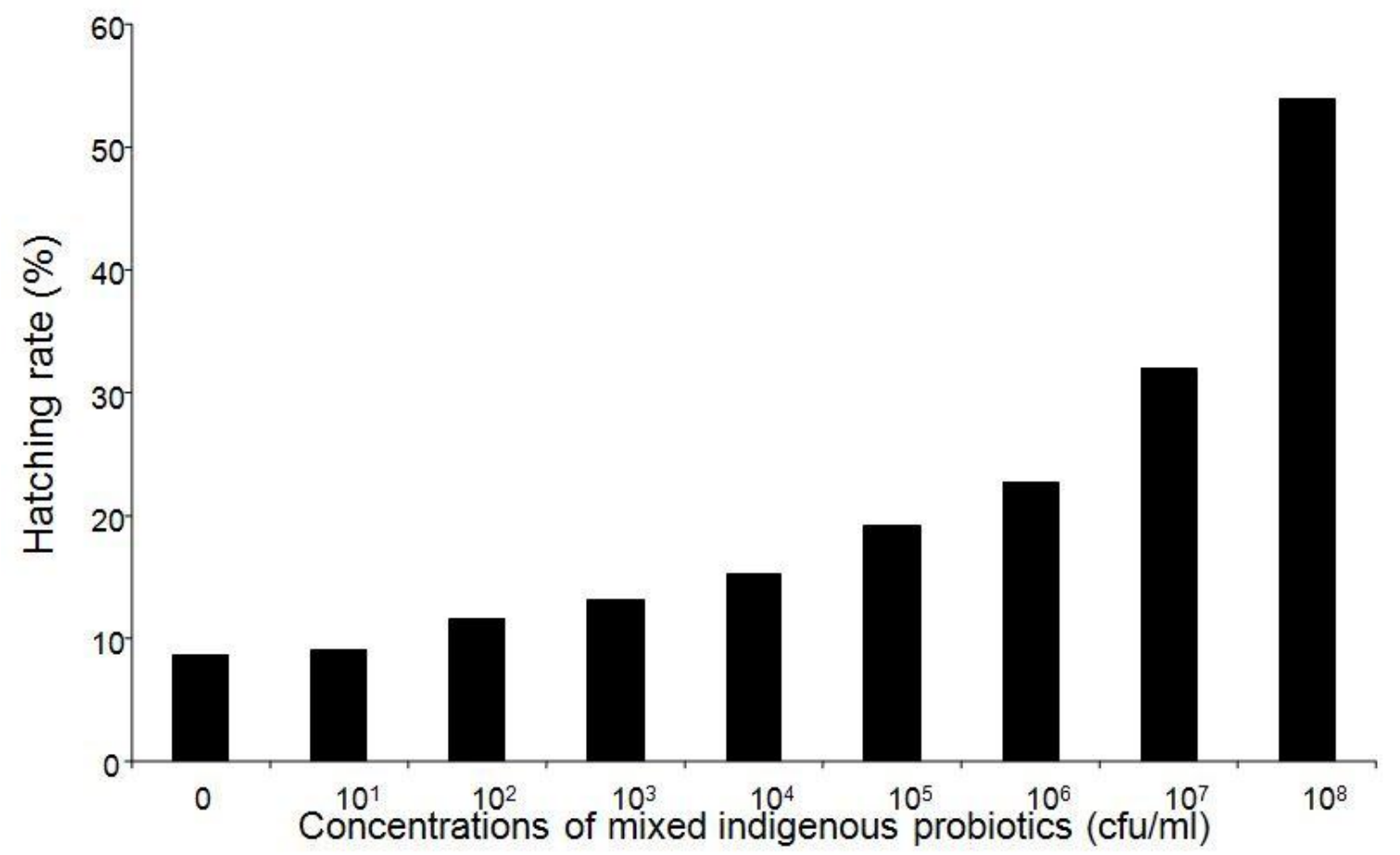

Figure 2. Hatching rate of Clarias gariepinus eggs exposed to different concentrations of mixed indigenous probiotics. 
ARIOLE, C. N.; OKPOKWASILI, G. C. The effect of indigenous probiotics on egg hatchability and larval viability of Clarias gariepinus. Ambi-Agua, Taubaté, v. 7, n. 1, p. 81-88, 2012. (http://dx.doi.org/10.4136/ambi-agua.712)

Table 2. Survival (mean \pm SD) of Clarias gariepinus eggs and larvae exposed to different mixed indigenous probiotics.

\begin{tabular}{|c|c|c|c|c|c|c|c|c|}
\hline \multirow[b]{2}{*}{$\begin{array}{l}\text { Concentration } \\
\text { of indigenous } \\
\text { probiotics } \\
\text { (cfu/ml) }\end{array}$} & \multicolumn{3}{|c|}{ Egg period } & \multicolumn{2}{|c|}{ Hatching period } & \multicolumn{3}{|c|}{ Yolk sac period } \\
\hline & $\begin{array}{c}\text { Initial } \\
\text { number } \\
\text { of eggs }\end{array}$ & $\begin{array}{c}\text { Survivors } \\
\text { to } \\
\text { hatching } \\
\text { period }\end{array}$ & $\begin{array}{c}\text { Egg } \\
\text { survival } \\
(\%)\end{array}$ & $\begin{array}{c}\text { Survivors } \\
\text { to end of } \\
\text { hatching } \\
\text { period }\end{array}$ & $\begin{array}{c}\text { Survival } \\
\text { from end of } \\
\text { egg period } \\
(\%)\end{array}$ & $\begin{array}{l}\text { Survivors } \\
\text { to end of } \\
\text { yolk sac } \\
\text { period }\end{array}$ & $\begin{array}{c}\text { Survival } \\
\text { from end of } \\
\text { hatching } \\
\text { period }(\%)\end{array}$ & $\begin{array}{c}\text { Survival } \\
\text { from end } \\
\text { of egg } \\
\text { period } \\
(\%)\end{array}$ \\
\hline $0 *$ & 23 & 2 & $8.70 \pm 0.42$ & 2 & $100.00 \pm 0.00$ & 0 & $0 \pm 0.00$ & $0 \pm 0.00$ \\
\hline $10^{1 *}$ & 33 & 3 & $9.09 \pm 0.81$ & 3 & $100.00 \pm 0.00$ & 0 & $0 \pm 0.00$ & $0 \pm 0.00$ \\
\hline $10^{2}$ & 69 & 8 & $11.59 \pm 0.53$ & 8 & $100.00 \pm 0.00$ & 3 & $37.5 \pm 0.11$ & $37.5 \pm 0.91$ \\
\hline $10^{3}$ & 38 & 5 & $13.16 \pm 0.62$ & 4 & $80.00 \pm 0.23$ & 2 & $50.00 \pm 0.23$ & $40.00 \pm 0.82$ \\
\hline $10^{4}$ & 33 & 5 & $15.15 \pm 0.72$ & 4 & $40.00 \pm 0.59$ & 2 & $50.00 \pm 0.90$ & $40.00 \pm 0.73$ \\
\hline $10^{5}$ & 26 & 5 & $19.23 \pm 0.94$ & 4 & $80.00 \pm 0.61$ & 2 & $50.00 \pm 0.81$ & $40.00 \pm 0.51$ \\
\hline $10^{6}$ & 44 & 10 & $22.73 \pm 0.12$ & 8 & $80.00 \pm 0.72$ & 5 & $62.5 \pm 0.72$ & $50.00 \pm 0.22$ \\
\hline $10^{7}$ & 25 & 8 & $32.00 \pm 0.12$ & 5 & $62.5 \pm 0.83$ & 4 & $80.00 \pm 0.89$ & $50.00 \pm 0.33$ \\
\hline $10^{8}$ & 26 & 14 & $53.85 \pm 0.33$ & 12 & $85.71 \pm 0.91$ & 10 & $83.33 \pm 0.14$ & $71.43 \pm 0.97$ \\
\hline
\end{tabular}

* All the yolk sac larvae at these concentrations died before the end of yolk sac period.

These results imply that Clarias gariepinus developing embryos were quite sensitive to higher bacterial load since the incubation time and hatching rate increased with increase in bacterial load.

All yolk- sac larvae at 0 and $10^{1} \mathrm{cfu} / \mathrm{ml}$ died before the end of yolk - sac period (Table 2). Table 3 revealed that the hatching rate observed at $0 \mathrm{cfu} / \mathrm{ml}$ (dilution water) was significantly lower than all the other hatching rates observed at the other concentrations. Furthermore, the highest larval survival of $71.43 \%$ recorded at $10^{8} \mathrm{cfu} / \mathrm{ml}$ where the highest hatching rate was observed, was significantly higher than larval survival rate observed at the other concentrations.

Table 3. Mean ( $\pm \mathrm{SD})$ Comparison for Clarias gariepinus egg hatchability and larval survival at different levels of mixed indigenous probiotics.

\begin{tabular}{c|c|c}
\hline $\begin{array}{c}\text { Concentration of mixed } \\
\text { indigenous probiotics } \\
(\mathbf{c f u} / \mathbf{m l})\end{array}$ & $\begin{array}{c}\text { Hatchability } \\
(\boldsymbol{\%})\end{array}$ & $\begin{array}{c}\text { Larval survival } \\
(\boldsymbol{\%})\end{array}$ \\
\hline $\mathbf{0}$ & $8.70^{\mathrm{m}} \pm 0.42$ & $0^{\mathrm{m}}$ \\
$\mathbf{1 0}^{\mathbf{1}}$ & $9.09^{\mathrm{d}} \pm 0.81$ & $0^{\mathrm{m}}$ \\
$\mathbf{1 0}^{\mathbf{2}}$ & $11.59^{\mathrm{e}} \pm 0.53$ & $37.50^{\mathrm{a}} \pm 0.91$ \\
$\mathbf{1 0}^{\mathbf{3}}$ & $13.16^{\mathrm{a}} \pm 0.62$ & $40.00^{\mathrm{b}} \pm 0.82$ \\
$\mathbf{1 0}^{\mathbf{4}}$ & $15.15^{\mathrm{b}} \pm 0.72$ & $40.00^{\mathrm{b}} \pm 0.73$ \\
$\mathbf{1 0}^{\mathbf{1 0}}$ & $19.23^{\mathrm{x}} \pm 0.94$ & $40.00^{\mathrm{b}} \pm 0.51$ \\
$\mathbf{1 0}^{\mathbf{7}}$ & $22.73^{\mathrm{y}} \pm 0.12$ & $50.00^{\mathrm{e}} \pm 0.22$ \\
$\mathbf{1 0}^{\mathbf{8}}$ & $32.00^{\mathrm{z}} \pm 0.12$ & $50.00^{\mathrm{e}} \pm 0.33$ \\
\hline
\end{tabular}

Note: Mean values within each column which do not have the same superscript letter are significantly different $(\mathrm{p}<0.05)$.

The higher egg and larval survival with increase in bacterial load is probably due to the fact that they were used as sources of exogenous carbon and energy or had an otherwise beneficial effect on survival. It has been observed that survival of halibut (Hippoglossus hippoglossus) larvae in the first 2 weeks after hatching is affected by 
ARIOLE, C. N.; OKPOKWASILI, G. C. The effect of indigenous probiotics on egg hatchability and larval viability of Clarias gariepinus. Ambi-Agua, Taubaté, v. 7, n. 1, p. 81-88, 2012. (http://dx.doi.org/10.4136/ambi-agua.712)

incubation with indigenous bacteria isolated from fish (Olafsen, 1998). Probiotics are known to confer a healthy effect on the host as significant microbial food supplements in the field of prophylaxis (Geovanny et al., 2007). A relatively dense, non pathogenic and diverse adherent microbiota present on the eggs would probably be an effective barrier against colony formation by pathogens on fish eggs (Hansen et al., 1992; Olafsen, 1998).

Several experiments and observations suggest that poor survival, growth and quality of larvae to a large extent can be explained by microbial conditions during egg and yolk sac stages (Bergh and Hjelmert, 1990 ; Salvesen et al., 1991; Lein et al.,1992) and during first feeding (Gatesoupe, 1991). But the bacteria used in challenging the egg and larval culture were non-pathogens previously isolated from the eggs and larvae as normal flora. However, a high load of organic matter and bacteria as well as substantial variation in the environmental conditions of the bacteria may change the normal interaction between bacteria and larvae to one that is detrimental (Vadstein et al., 1993).

Therefore, further investigation is needed in order to establish the threshold concentration of the bacterial load in water as well as those colonizing the eggs and larvae that will inhibit hatching and larval survival in the hatchery.

\section{CONCLUSIONS}

From the results of this experiment, it can be concluded that a mixture of indigenous bacteria composed of Bacillus, Pseudomonas, Acinetobacter and Flavobacterium previously isolated from aquatic environment has a beneficial impact on survival of eggs and larvae of Clarias gariepinus. The hatching rate and larval survival increased with increasing bacterial load up to $10^{8}$ cells $/ \mathrm{ml}$, the highest dose employed. Therefore, further investigations are needed to demonstrate the optimal and threshold doses.

\section{ACKNOWLEDGEMENTS}

The authors wish to acknowledge the assistance of the management and staff of African Regional Aquaculture centre (ARAC) Aluu, Port-Harcourt, during the course of the experiments.

\section{REFERENCES}

ABDELHAMID, A. M. Recent trends in fish culture. Alexandria: New University office, 2009.

BERGH, $\varnothing$.; HJELMERT, A. Antibacterial treatment of eggs of halibut (Hippoglossus hippoglossus L.). ICES report, v. 39, 1990.

DELINCE, G. A.; CAMPBELL, D.; JANSEN, J. A. L.; KUTTY, M. N. Seed production. Port-Harcourt : African Regional Aquaculture Centre (ARAC), Aluu, 1987.

GATESOUPE, F. J. The use of probiotics in fish hatcheries: Results and prospect. ICES report, v. 37, 1991.

GEOVANNY, G. R.; LUIS, B. J.; SHEN, M. A. Probiotics as control agents in aquaculture. J. Ocean Univ. China, v. 6, p. 76-79, 2007.

http://dx.doi.org/10.1007/s11802-007-0076-8 
ARIOLE, C. N.; OKPOKWASILI, G. C. The effect of indigenous probiotics on egg hatchability and larval viability of Clarias gariepinus. Ambi-Agua, Taubaté, v. 7, n. 1, p. 81-88, 2012. (http://dx.doi.org/10.4136/ambi-agua.712)

GODA, A. M. A. S.; El -HAROUN, E. R.; CHOWDHURY, M. A. K. Effects of totally or partially replacing of fish meal by alternative protein sources on growth of Africa catfish Clarias gariepinus (Burchell, 1822) reared in concrete tanks. Aquacult. Res. v. 38, p. 279-287, 2007. http://dx.doi.org/10.1111/j.1365-2109.2007.01663.x

HANSEN, G. H.; STR ØM, E.; OLAFSEN, J. A. Effects of deferent holding regimens on the intestinal microflora of herring (Clupea harengus) larvae. Appl. Environ. Microbiol. v. 58, p. 461-470, 1992.

KIM, S.; NONAKA, L.; SUZUKI, S. Occurrence of tetracycline resistance genes tet (M) and tet $(\mathrm{S})$ in bacteria from marine aquaculture sites. FEMS Microbial. Lett. v. 237, p. 147-156, 2004. http://dx.doi.org/10.1111/j.1574-6968.2004.tb09690.x

LEIN, I.; GULBRANDSEN, J.; HOLMEFJORD, I.; REFSTIE, T.; BOLLA, S.; OLSEN, Y. et al. Progress in larviculture of the Atlantic halibut Hippoglossus hippoglossus. Med. Fac. Landbouww. Univ. Gent., v. 57, n. 46, p. 2099-2110, 1992.

MOLOKWU, C. N.; OKPOKWASILI, G. C. Microbial flora of Clarias gariepinus in the early stages of development. Tropical Freshwater Biology, v. 11, p. 91-100, 2002.

OLAFSEN, J. A. Interactions between hosts and bacteria aquaculture. In: US-EC WORKSHOP ON MARINE MICROORGANISMS: RESEARCH ISSUES FOR BIOTECHNOLOGY, 1998, Brussels. Proceedings... Brussels: European Commission, 1998. p. 127-145.

OSMAN, A. G. M.; WUERTZ, S.; MEKKAWY, I. A. A.; EXNER, H.; KIRSCHBAUM, F. Embryo -toxic effects of lead nitrate of the African catfish Clarias gariepinus (Brurchell 1822). J. Ichthyol, v. 23, p. 48-58, 2007.

SAHU, M. K.; SWARNAKUMAR, N. S.; SIVAKUMAR, K.; THANGARADJOU, T.; KANNAN, L. Probiotics in aquaculture: Importance and future perspectives. Indian J. Microbiol. v. 48, p. 299 -308, 2008. http://dx.doi.org/10.1007/s12088-008-0024-3

SALVESEN, I.; JØRGENSEN, L.; VADSTEIN, O. Evaluation of four chemicals for surface disinfection of marine fish eggs. European Aquaculture Society, Special Publication, n. 15, p. 406-408, 1991.

SMITH, P.; HINEY, M. P.; SAMUELSEN, O.B. Bacterial resistance to antimicrobial agents used in fish farming: a critical evaluation of method and meaning. Annu. Rev. Fish. Dis. v. 4, p. 273-313, 1994. http://dx.doi.org/10.1016/09598030(94)90032-9

SØRUM, H. Antimicrobial drug resitance in fish pathogens. In: AARESRUP, F. M. (Ed.). Antimicrobial resistance in bacteria of animal origin. Washington DC.: ASM Press, 2006. p. 213-238.

VADSTEIN, O.; ØIE, G.; OLSEN, Y.; SALVESEN, I.; SKJERMO, J.; SKJA K-BRAEK, G. A. Strategy to obtain microbial control during larval development of marine fish. In: REINERTSEN, H.; DAHLE, L. A.; JØRGENSEN, L.; TVINNEREIM, K. (Eds.). Fish farming technology. Rotterdam: Balkema, 1993. p. 69-75.

WORLD HEALTH ORGANIZATION - WHO. Joint FAO/NACA/WHO studying group on food safety issues associated with products from aquaculture. Technical Report Series, n. 883, 1999. 
ARIOLE, C. N.; OKPOKWASILI, G. C. The effect of indigenous probiotics on egg hatchability and larval viability of Clarias gariepinus. Ambi-Agua, Taubaté, v. 7, n. 1, p. 81-88, 2012. (http://dx.doi.org/10.4136/ambi-agua.712)

WORLD HEALTH ORGANIZATION - WHO. Report of a Joint FAO/OIE/WHO expert consultation on antimicrobial use in aquaculture and antimicrobial resistance: Seoul, Republic of Korea, 13-16 June, 2006. Available in: <http://www.who.int/topics/foodborne_diseases/aquaculture_rep_13_16june2006\%2 0.pdf>. Access in: 23 Feb. 2011. 